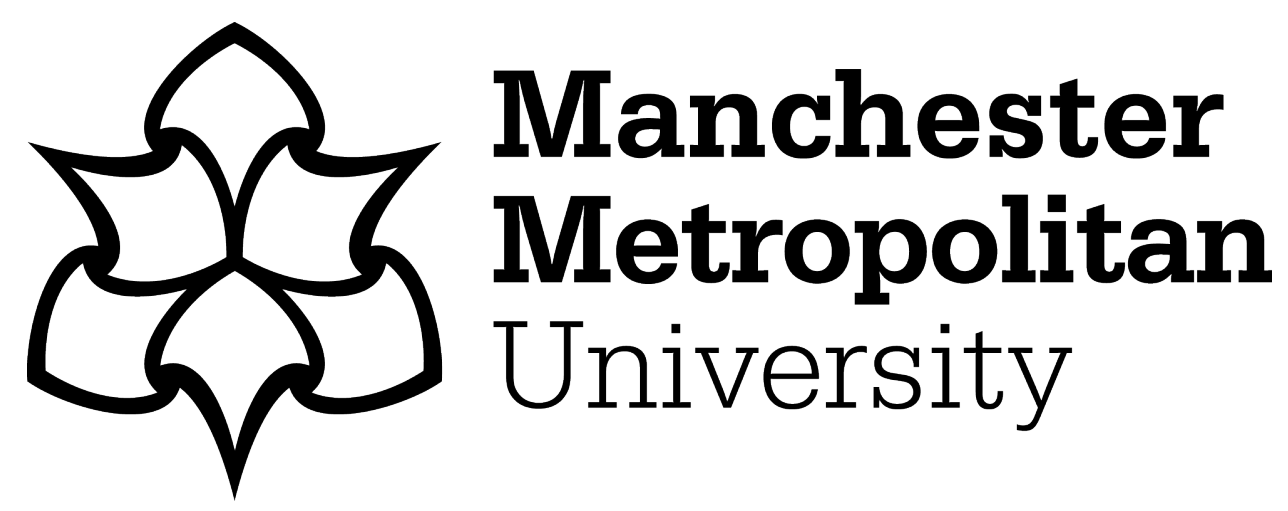

Rowley, JE and Fullwood, WR (2018) Promoting volunteer engagement in the heritage sector. Journal of Cultural Heritage Management and Sustainable Development, 8 (3). pp. 362-371. ISSN 2044-1266

Downloaded from: https://e-space.mmu.ac.uk/620254/

Version: Accepted Version

Publisher: Emerald

DOI: https://doi.org/10.1108/JCHMSD-06-2017-0042

Please cite the published version 


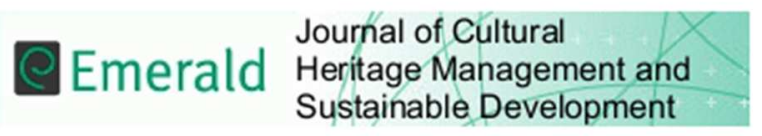

Promoting volunteer engagement in the heritage sector

\begin{tabular}{|r|l|}
\hline Journal: & Journal of Cultural Heritage Management and Sustainable Development \\
\hline Manuscript ID & JCHMSD-06-2017-0042.R3 \\
\hline Manuscript Type: & Practitioner Paper \\
\hline Keywords: & heritage, volunteer engagement, volunteer development \\
\hline \multicolumn{2}{|c}{} \\
\hline
\end{tabular}

SCHOLARONE $^{\text {m }}$

Manuscripts 


\title{
Promoting volunteer engagement in the heritage sector
}

\begin{abstract}
Purpose: This article offers insights into the processes associated with promoting volunteer engagement adopted by a large UK heritage attraction during a period of significant change. Engaged volunteers were regarded as essential to sustain, and where appropriate, to enhance the customer experience.
\end{abstract}

Approach: A case study approach was adopted. This involved review of relevant documentation and interviews and focus groups between researchers, managers and volunteers.

Findings: Working from the philosophical stance that information and involvement are strong predecessors to 'buy-in', the managers of the attraction used a series of initiatives that kept volunteers both informed and involved. These initiatives include a values-based induction programme, information and communication, training and development, and creating new narratives.

Originality/value: Volunteer engagement influences volunteer commitment to the organisation. This case study offers some insights into initiatives adopted in one heritage organisation to promote volunteer engagement, and thereby provides a basis for other organisations to reflect on their practices in this area.

Keywords: volunteer engagement; volunteer development; heritage; National Trust

\section{Article Classification: Case study}

\section{Introduction}

\section{Volunteers and their contribution}

Volunteers are making an increasing contribution in heritage settings and often act as the main point of contact with visitors in their roles as guides, stewards and ticketing assistants. In addition, they may take on a number of other roles such as estate maintenance, gardening, education, office work and contributing to heritage narratives. Successive governments in the UK have prioritised the promotion of volunteering in the UK. The origins of this policy direction can be traced back to John Major's "make a difference" initiative. Accordingly, volunteering has also been seen as a way of implementing government policy and in recent years, substantial sums have been allocated to volunteer infrastructure (Rochester et al., 2010). This is reflected in the latest statistics on volunteering which suggest that $41 \%$ of people in the UK took part in formal volunteering at least once a month in 2015-2016 and $60 \%$ informally volunteered during the same period (Cabinet Office, 2016). Volunteers are to be found in a wide range of activities including sport, health, religion, community and the environment. The Sports/exercise and Hobbies/recreation/arts/social club categories were 
found to have the highest percentage of volunteers (NCVO Almanac, 2016). Furthermore, the estimated value of volunteer output to the UK was 23.9 billion in 2012 , which equated to $1.5 \%$ of GDP (Foster, 2013).

In global terms, volunteers make up a sizeable part of the working population in most OECD countries (OECD, 2017). However, there are significant differences in the rate of volunteering in different countries. These range from $7 \%$ in Greece to $40 \%$ in Canada (OECD, 2017). In fact the highest rates of volunteering generally occur in English speaking countries (Holmes and Smith, 2012). There has also been an upward trend globally in rates of volunteering between 2008 and 2014 (OECD, 2017), although global data on heritage volunteering is scarce. The European Heritage Volunteers project has focussed for over 20 years on arranging short term heritage volunteering assignments for young people all over Europe (European Heritage Volunteers, 2017). Similarly, the World Heritage Volunteers Initiative was launched by UNESCO in 2008 and since the 3500 young volunteers have participated in action camps. With regard to the heritage sector in the UK, the National Trust currently has 62,000 volunteers contributing 3.9 million hours (National Trust, Fascinating Facts and Figures, 2017) and is also the largest voluntary conservation organisation in Europe (National Trust, Conservation Principles, 2017). In contrast, English Heritage has 2000 volunteers working across 36 sites (English Heritage, Facts and Figures, 2017). MurzynKupisz and Działek, (2013) believe that volunteering in a heritage environment promotes a feeling of well-being and integration in the local community as well as enhancing social capital. However, despite the importance of volunteers to cultural attractions, such as museums, Edwards and Graham (2006) and Stameer et al. (2008) suggest that there is a need for further research into the organisational challenges facing organisations that use volunteers.

Holmes and Smith (2012) suggest heritage volunteers can be categorised in different ways. In terms of roles, front of house volunteers typically meet, greet and impart site information to visitors, whilst behind the scenes volunteers undertake repair and maintenance tasks which entail much less contact with visitors. With regard to patterns of attendance, volunteering can be episodic, ongoing or seasonal (Holmes and Smith, 2012). Episodic volunteering, in particular, is a growing trend. Episodic volunteering focusses on short time periods, although volunteers can sometimes return each year with enhanced knowledge and experience (Bryen and Madden, 2006).

On the other hand, not all commentators regard this increasing dependence on volunteers as a positive move, pointing to the potential impact of a growing volunteer workforce on paid employment opportunities. For example, fears have been raised about the growing reliance by the government on volunteers to provide public services in order to lessen its responsibilities and make financial savings (Cuskelly et al,. 2006). Others have also seen the practice of substituting volunteers directly for paid employees as undesirable. Volunteering England and the TUC (2009) point out that volunteers should be seen as complementing and supplementing paid staff. Handy et al. (2008) also refer to the interchangeability of volunteers and paid staff in a variety of roles. In addition, some researchers point to the extent to which volunteering can re-enforce existing class differences. For example, Harflett (2015) 
comments on the predominantly white, middle-class profile of regular property-based National Trust volunteers, and links to volunteer's cultural capital. Nevertheless, if the heritage sector is to become increasingly dependent on volunteers it is important to optimise the benefits of their contribution to both volunteers and heritage sector organisations.

\section{Volunteer management and development}

An increase in the numbers and importance of volunteers in the heritage sector has fuelled interest in volunteer management. On the other hand, there is a recognition that the human resource management practices that are used with employed staff may not be transferrable to volunteers (Newton et al., 2014). Volunteers are different to paid employees in several respects, including their rather different formal and psychological contractual relationship with their 'employer', the predominant part-time nature of their involvement, and, increasingly, their age profile. Wilson (2012) indicates that rates of volunteering peak in midlife, but decrease in later life. Volunteers bring a variety of skills and knowledge developed in other settings to their role as a volunteer (Kemp, 2002). Moreover, Brayley et al. (2014) suggest that older people are looking for greater variety in their opportunities to volunteer along with a more short-term approach that mirrors their own interests.

Most of the research on volunteer management centres on motivation, retention and engagement and the relationship between these variables and their influencers (e.g. Chen and Yu, 2014; Clary and Snyder, 1991; Garner and Garner, 2011; Vecina et al., 2012). Clary and Snyder's influential Volunteer Functions Inventory (VFI) measured six motives for volunteering and formed the basis for many subsequent surveys (Clary et al., 1998). This was developed into a strategy for recruitment, placement, and retention of volunteers (Clary et al., 1998). Vecina et al. (2012) demonstrated that engagement is essential to satisfaction in the initial stage of volunteering and that satisfaction in turn leads to intention to continue. Furthermore, volunteer engagement is regarded as particularly important in explaining participant's commitment to an organisation (Alfes et al., 2016; Vecina et al., 2012). The critical importance of retention is stressed by Garner and Garner (2011) who suggest that being able to voice an opinion positively affects volunteer retention and it itself a source of valuable feedback for the organisation. Moreover, Studer (2015) believes that some organisations forget that volunteers themselves should be considered as unique stakeholders within the organisation. However, whilst this prior research contributes to identifying some of the factors that influence volunteer engagement, it does not offer any insights into the processes and approaches that can be adopted to cultivate volunteer engagement. One exception is the research by Curran et al. (2016) that suggests that brand heritage stimulates volunteer engagement.

With a view to contributing to addressing the gap regarding the processes associated with volunteer engagement, the aim of this article is to generate insights into approaches to volunteer engagement through a case study analysis of a UK heritage attraction in which a programme of volunteer development has successfully contributed to volunteer engagement. The article does this by first discussing the case context, and the need for change, and then describing and critically evaluating the programme of initiatives for promoting the engagement of volunteers in the change agenda. 


\section{Case Context}

The character of the attraction

This article reports on a change management programme initiated at the heritage attraction, Dunham Massey, one of the estates in the (UK) National Trust portfolio. Dunham Massey is based on a site in the North West of England, near to Manchester, and is set in 300 acres of ancient woodland and gardens. It has an extensive estate, much of which is farmed by tenant farmers. The main site includes a mansion, visitor centre, shop and restaurant. Further afield, there are cultivated gardens, a lake, and a herd of deer. A learning programme regarding the history of the site for schoolchildren is also provided (National Trust, Dunham Massey, 2017).

Although the history of the Dunham Massey estate extends back to the Elizabethan era, the current house dates primarily from 1732-40 when it was extensively remodelled by John Norris for the 2nd Earl of Warrington. More recent alterations were made in 1789 and 1905 when a neo-Caroline façade and Edwardian interiors were added. The 10th Earl of Warrington, who did a great deal to preserve the estate from development in the mid-20th century, left Dunham to the National Trust in 1976 - one of the most generous gifts in the Trust's history. Housed within the hall is an extensive collection of silver, furniture, portraits, costume and domestic textiles, as well as a gentleman's library (National Trust, Dunham Massey Collections, 2017).

\section{The volunteer workforce}

Dunham Massey is located on the edge of a major conurbation, and as such, it has the opportunity to both contribute to and benefit from a local community. Many of the volunteers are recruited from the local area, and whilst the attraction draws in national and international visitors, the local community also provides a steady flow of visitors.

The attraction has around five hundred volunteers offering their time as room guides, greeters and learning assistants as well as staffing the gift shop. On the estate, volunteers take on roles as gardeners and park rangers. House volunteers also work with the contents and collections and many have a strong interest in the history of the property. All volunteers are encouraged to work at least once a fortnight. There is a considerable variation in the number of hours contributed by volunteers, and in the length of time that they have been volunteering at the site. Volunteers are managed by paid staff and volunteer managers. Many of these managers are taking on a challenging role early in their careers in the heritage sector, and themselves benefit from appropriate support and development. The role is challenging due to the number of people with whom the volunteer managers need to interact, and their diverse backgrounds and skills. In addition to the volunteer managers, the larger teams also have day organisers, who are volunteers who assist staff in coordinating the team and its rotas. Given their pivotal roles in volunteer engagement and development, the organisation invests heavily in the training, development and support of both volunteer managers and day organisers. 


\section{The Change agenda}

Dunham Massey has undergone a significant change programme in the last five years. Much of this change has been informed by the National Trust's agenda in the areas of 'Protecting the natural environment' and 'Investing in the nation's heritage' (National Trust, Our plan to nurse the environment back to health, 2016). The organisation is, for example, seeking to 'develop new, innovative ways of managing land on a large scale, which are good for farmers, the economy and the environment'. They also intend to 'spend more than ever on looking after our historic houses and collections, clearing the backlog of repairs' and to 'help local communities to look after the heritage that is important to them', as well as 'working harder to give visitors experiences that are emotionally rewarding, and intellectually stimulating'.

The challenge facing the management at Dunham Massey (and other National Trust properties) was to mobilise those whom they rely on to deliver on such aspirations, in an organisational setting in which the ratio of paid staff to volunteers is 1:6. The success of the change programme was heavily dependent on 'buy-in' from a volunteer workforce that had previously been relatively unaccustomed to change, had other key priorities in their lives and, were sometimes change resistant.

\section{Methodology}

A case study approach was adopted in this research because the purpose of the study was to conduct exploratory research that generated insights into a real-life phenomenon, the processes associated with the cultivation of volunteer development, where the boundaries between the phenomenon and its context are unclear (Yin, 1994). A single case study was deemed to be appropriate in this instance, because it offered the opportunity to capitalise on a unique initiative that might have potential interest in other contexts, and which could also act as a preliminary study to further research in other contexts (Rowley, 2002).

The primary method of data gathering for the research reported in this article was documentary analysis of various internal documents relating to the volunteer engagement initiative, including policy documents, programmes of activities and events, and reports.

The documentary analysis was supplemented by insights from interviews with managers and focus groups with volunteers at the attraction. These included an in-depth interview with the Volunteer Development Manager, eight interviews with managers and six focus groups with volunteers. These interviews and focus groups were conducted as part of a wider study on volunteer development, the detailed findings from which are reported elsewhere. In this article, selective comments are mined from this dataset to illustrate and support some of the comments in the Findings section. 


\section{Findings}

Over the past four years a programme of volunteer engagement (with change) centring on volunteer development and community building has been rolled out. This programme involved: a values and behaviours-based induction programme, information and communication, training and development and, creating new narratives.

At the centre of a coordinated and innovative approach to volunteer engagement was a fulltime Volunteer Development Manager. The Volunteer Development Manager was responsible for overseeing the direction and development of volunteering, and over the six years that she was in post, played a key role in promoting volunteer engagement, often in tandem with volunteer development. Initiatives developed over this period include both 'conventional' induction and training, as well as structured opportunities for community building and learning together. They include:

\section{A Values and behaviours-based induction programme}

Every volunteer is expected to participate in an induction programme. This includes: shadowing other volunteers, briefing on their role and how things work in the organisation, orientation exercises and guided tours around the site, and support from managers and fellow volunteers. A key part of induction is an introduction to the organisation's values and behaviours, which, whilst they place expectations on the volunteers, also articulate the culture to which the organisation seeks to aspire. The values and behaviours have two strands: 'inspire people'; and, 'think long term' (Table 1).

\begin{tabular}{|l|l|}
\hline Inspire people & $\begin{array}{l}\text { We inspire people to love special places. We're warm, welcoming and } \\
\text { actively part of the communities around us. We encourage and listen to } \\
\text { other people's views, needs and suggestions and we exceed peoples' } \\
\text { expectation with our positive 'can-do' attitude. We thrive by involving } \\
\text { people in what we do, inspiring them to share our passion for special } \\
\text { places }\end{array}$ \\
\hline Think long term & $\begin{array}{l}\text { We look after special places for people for ever. We're dynamic, far- } \\
\text { sighted and ready to lead for the long term. We behave in a sustainable } \\
\text { way, reducing our impact on the environment and spending wisely to } \\
\text { make sure that we have the financial security to look after special places } \\
\text { for ever. We keep things simple and are imaginative about finding } \\
\text { better ways to do things. }\end{array}$ \\
\hline
\end{tabular}

Table 1: National Trust Values and Behaviours

\section{Information and Communication}

All volunteers have a manager whom they can contact at any time with problems, questions or comments. Also, every day, during opening hours, there is either a Duty Manager or Duty Staff team available for support, advice, and if necessary, interventions.

The National Trust conducts an annual volunteer survey (National Trust Annual Report, 2016), which allows volunteers to express their opinions. The site shares this data with 
volunteers and uses it to inform developments on site, often involving volunteers in discussions about this work. Further, all volunteers are expected to attend one of the preseason meetings, to keep them up-to-date with developments planned for the year ahead. More recently, feedback from the annual customer satisfaction survey (National Trust Annual Report, 2016) has also been shared with volunteers, with a view to better empowering them to focus their suggestions and recommendations, leading to more productive exchanges with each other and with their managers.

The National Trust has recently rolled out a web space for volunteers called Myvolunteering. This package keeps a personal profile of every volunteer, allows them to claim expenses, and operates rotas. Its backroom database, Yourvolunteering, is accessed by volunteer managers. It is used to store personal data, log volunteer hours and training records and, generally, it assists with volunteer management. Through this platform, each National Trust site can share property specific information with its volunteers as well as a collection of information and resources about the National Trust and its other sites.

\section{Training and development}

Since 2012, the site has developed a volunteer training and development programme, $A M a$ Puissance; this includes talks, walks, visits, tours, workshops, activities and lectures on subjects related to the organisation's work. The title of this programme is taken from Dunham Massey's family motto, which translates to 'the best of my strength' and is carved in stone above the front door of Dunham Massey.

Some sessions are mandatory, but most are voluntary. These sessions are not only designed to develop volunteers' skills, but also to promote their interest in the site and its heritage, and to offer opportunities for socialising, networking and community building. One example cited by the Volunteer Development Manager was where volunteers worked with an artistic director in order to bring aspects of Dunham's history to life for the visitors.

Since 2014, Dunham Massey's visitor experience has focused around two different narratives, one after another. The first of these was 'Sanctuary from the Trenches', which told the story of the mansion's use as a First World War hospital. The second was 'Dunham's Lost Years' which tells the tale of the $7^{\text {th }}$ Earl's controversial marriage to a circus equestrienne (National Trust, Dunham Massey, 2017). These immersive exhibitions have narrowed the visitor experience to explore a specific moment in time, therefore requiring the property's visitor facing workforce to be able to impart their knowledge of these stories to the public (National Trust, Dunham's Lost Years, 2016).

Applying the theory that 'Communication + Involvement = Buy-In', Dunham Massey implemented a programme of change that sought to breed excitement amongst volunteers, as well as engage their support, and increase their knowledge and skills.

A Ma Puissance commenced in preparation for Sanctuary from the Trenches, and has been running since 2012. Table 2 provides examples of the activities/events in these programmes in seasons 3 and 6 . Both the target audiences and the topics of the events change from year to 
year, responding to key changes at Dunham Massey at the time. So, for example, in season 3, in support of the development of the exhibition 'Sanctuary from the Trenches' several of the sessions were open to all volunteers and were aimed at ensuring that volunteers had a good understanding of the First World War context and Dunham Massey's role in the war. Season 6's operational sessions focussed on developing practical skills and knowledge that are required to fulfil specific roles (e.g. plant propagation workshop for gardeners), and compulsory health and safety briefings (e.g evacuation procedures for room guides), whilst the contextual sessions focussed on the property's current Victorian story. Several of these sessions were run in collaboration with other organisations, such as the John Rylands Library of the University of Manchester, in order to capitalise on the expertise of professional and researchers.

\begin{tabular}{|c|c|c|}
\hline Title of event & Nature of event & Audience \\
\hline \multicolumn{3}{|l|}{ Season 3} \\
\hline $\begin{array}{l}\text { Britain and the First World } \\
\text { War }\end{array}$ & Lecture & All volunteers \\
\hline AMP Book Club & $\begin{array}{l}\text { Book club, centred on two non- } \\
\text { fiction books on what life was like } \\
\text { in the first world war }\end{array}$ & All volunteers \\
\hline AMPlified & $\begin{array}{l}\text { Choir event with volunteers at a } \\
\text { public venue in Manchester, with } \\
\text { songs based on those from } 1914\end{array}$ & All volunteers \\
\hline $\begin{array}{l}\text { Sanctuary from the } \\
\text { Trenches; a country house at } \\
\text { war }\end{array}$ & $\begin{array}{l}\text { Briefing and pre-view tour of the } \\
\text { new exhibition }\end{array}$ & $\begin{array}{l}\text { Compulsory for All } \\
\text { Volunteers }\end{array}$ \\
\hline $\begin{array}{l}\text { Stamford Hospital }-\mathrm{An} \\
\text { Induction for room guides }\end{array}$ & On site induction & All room guides \\
\hline $\begin{array}{l}\text { Nursing during the First } \\
\text { World War }\end{array}$ & Lecture & All volunteers \\
\hline \multicolumn{3}{|l|}{ Season 6} \\
\hline $\begin{array}{l}\text { Safe as houses (evacuation } \\
\text { procedures) }\end{array}$ & Briefing & $\begin{array}{l}\text { All room guides, } \\
\text { Room guide day } \\
\text { organisers, and tour } \\
\text { guides. }\end{array}$ \\
\hline Meet the mill man & $\begin{array}{l}\text { Briefing (health\& safety, } \\
\text { maintenance and interpretation) }\end{array}$ & $\begin{array}{l}\text { Park guides and mill } \\
\text { stewards }\end{array}$ \\
\hline $\begin{array}{lcl}\text { An } & \text { Introduction } & \text { to } \\
\text { rhododendron pruning } & \end{array}$ & Practical & $\begin{array}{l}\text { All Practical garden } \\
\text { volunteers }\end{array}$ \\
\hline Plant propagation workshop & Tour and practical & $\begin{array}{l}\text { All retail } \begin{array}{r}\text { and } \\
\text { practical garden } \\
\text { volunteers. }\end{array} \\
\end{array}$ \\
\hline George, & Briefing & All volunteers \\
\hline
\end{tabular}




\begin{tabular}{|l|l|l|}
\hline $\begin{array}{l}\text { Catherine: our journey } \\
\text { begins... }\end{array}$ & & \\
\hline The Victorians & Two-lecture series & All volunteers \\
\hline
\end{tabular}

Table 2 : Activities and events in change agenda programmes

\section{Creating new narratives}

Volunteers have contributed significantly to the new exhibitions and narratives. For example, in the development of the Sanctuary from the Trenches exhibition, which involved transforming the house to a hospital, volunteers were involved in:

'rummaging, photographing, and planning; lifting, vacuuming, polishing and rolling; pinning, stitching, ironing and folding; hammering, screwing, sanding, and drawing; debating, learning, reading and listening; raking, weeding, digging and building; sharing, understanding, waiting and supporting' (Your Guide to Stamford Hospital', NT, p.75).

More specifically volunteers were responsible for the research that sits behind the two recent major exhibitions as well as conserving the collection on display and making props and display items. These opportunities to be involved in these major developments at the property bred a sense of ownership amongst the volunteers, such that they positively embraced the changes. One example of this, recounted by the Volunteer Development Manager, demonstrated how volunteers who have been involved in substantial research share their knowledge by giving lectures to other volunteers.

We quite often organize lectures or talks where our volunteers, who've done huge amounts of research, talk about that and welcome questions, and we also share their papers. (Volunteer Development Manager).

Volunteers themselves share the enthusiasm about bringing history to life by wearing period costumes

We do our own research, what did they wear in those days, am I about right with the kind of things I'm wearing. That was useful and again supported by the Trust (Volunteer Focus Group)

Volunteers also contributed to the production of two major documents providing background information on the exhibitions.

We've done an oral history with one of our longest serving volunteers who's done a phenomenal amount of research into our archive, he's read all of the diaries and letters written by the last Earl, and this is like metres and metres and metres of library that he's read every page of.... (Volunteer Development Manager).

Rich with archival images, contextual background and the specifics of each storyline, a printed book was issued to each member of the Dunham Massey team. This serves as a 
learning tool, helping volunteers to familiarise themselves with the story but also as a souvenir, which is treasured by the volunteers.

When there's a different story to be told on different things, you get a lot of back-up information to that story and that's quite detailed so we got that for this story and for the WW1 story specifically printed. (Volunteer Focus Group).

\section{Discussion and conclusion}

Despite the debates regarding the potential for volunteers to undermine paid employment (Handy et al., 2008; Volunteering England, 2009; TUC, 2009), there is widespread and increasing use of volunteers across various sectors (OECD, 2017) including the heritage sector (European Heritage Volunteers, 2017). Heritage volunteers may adopt a wide range of different roles and have different patterns of attendance; they also bring different previous experience and skill sets to their role. Partly as the result of the non-contractual nature of their roles, managers and researchers have sought other ways to develop commitment (Alfes, et al., 2016) and retention (Garner and Garner, 2011), and have identified the pivotal role of volunteer engagement.

This article contributes to previous research on volunteer engagement by using a case study based approach to generate some insights into a programme that was implemented at one heritage site to support volunteer engagement during a time of change. It demonstrates an approach that extends beyond information provision to volunteer development and empowerment. Further, whilst in the early stages, sessions, for instance, in the $A M a$ Puisance programme were voluntary and incentivised, over time two parallel trends have assisted in the embedding of such training and other activities. Volunteers have started to value the opportunities for development, seeing them as a perk of their role as volunteers and even competing with other volunteers for opportunities. Alongside this, the management at Dunham Massey have developed a more strategic approach to volunteer development, and recognised its importance in volunteer management and in promoting volunteer engagement, and have capitalised on the link between volunteer development and change management, in a voluntary workforce.

The volunteer engagement programme that is reported and discussed in this article provides insights that can inform other heritage sites in their volunteer engagement strategies. In particular, it draws attention to both the link and differentiation between volunteer development and volunteer engagement. The research is also a useful point-of-departure for further research in other heritage contexts, and in other countries, where culture may influence volunteering processes and engagement. However, this research has two important limitations. First, it does not address the issue of the impact of volunteer development and engagement initiatives. Future research might usefully explore the impact of a variety of volunteer engagement initiatives on volunteer commitment and variation. Secondly, this article does not offer a systematic review of the perspectives of all stakeholders. Further 
research should be undertaken to explore different stakeholder's perspectives on the value of development programmes to volunteer engagement.

\section{References}

Alfes, K., Shantz, A. and Bailey, C (2016), "Enhancing volunteer engagement to achieve desirable outcomes: what can non-profit employers do?", Voluntas, Vol. 27 No. 2, pp.595617

Brayley, N., Obst, P., White, K.M., Lewis, I.M., Warburton, J. and Spencer, N.M. (2014), "Exploring the validity and predictive power of an extended volunteer functions inventory within the context of episodic skilled volunteering by retirees", Journal of Community Psychology, Vol. 42 No. 1, pp. 1-18.

Bryen, L.M. and Madden, K.M. (2006), Bounce-back of episodic volunteers: what makes episodic volunteers return? Working Paper No. CPNS 32.

Cabinet Office (2016), Community Life Survey 2015 to 2016: Technical Report, available at: https://www.gov.uk/government/publications/community-life-survey-2015-to-2016technical-report (accessed 28 June 2017)

Chen, C-F. and $\mathrm{Yu}, \mathrm{T}$. (2014), "Effects of positive vs negative forces on the burnoutcommitment-turnover relationship", Journal of Service Management, Vol. 25 No. 3, pp.388410 .

Clary, E.G., Snyder, M., Ridge, R.D., Copeland, J., Stukas, A.A., Haugen, J. and Miene, P. (1998) "Understanding and assessing the motivations of volunteers: a functional approach”, Journal of personality and social psychology, Vol. 74 No. 6, pp. 1516.

Curran, R., Taheri, B., MacIntosh, R. and O’Gorman, K. (2016), ”Nonprofit brand heritage: Its ability to influence volunteer retention, engagement, and satisfaction", Nonprofit and Voluntary Sector Quarterly, Vol. 45 No. 6, pp. 1234-1257.

Cuskelly, G., Hoye, R. and Auld, C. (2006) Working with volunteers in sport: Theory and practice, Routledge.

Edwards, D., Graham, M. (2006), "Museum volunteers: a discussion of challenges facing managers in the cultural and heritage sectors", Australian Journal of Volunteering, Vol.11 No.5, pp.19-27.

English Heritage Facts and figures (2017) available at: http://www.english-heritage.org.uk/about-us/search-news/press-releases/facts-and-figures/ (accessed 26 August).

European Heritage Volunteers (2017) http://www.heritagevolunteers.eu/ (accessed 24 August 2017)

Foster, R. (2013), Household Satellite Accounts - Valuing Voluntary Activity in the UK, Office of National Statistics, available at: 
http://webarchive.nationalarchives.gov.uk/20160105160709/http://www.ons.gov.uk/ons/dcp1 71766345918.

(accessed June 27, 2017)

Garner, J.T. and Garner, L.T. (2011), "Volunteering an opinion: Organizational voice and volunteer retention in nonprofit organizations", Nonprofit and Voluntary Sector Quarterly, Vol. 40 No. 5, pp. 813-828.

Handy, F., Mook, L. and Quarter, J. (2008), "The interchangeability of paid staff and volunteers in nonprofit organizations", Nonprofit and Voluntary Sector Quarterly, Vol. 37 No 1, pp. 76-92.

Harflett, N. (2015), "Bringing them with personal interests: the role of cultural capital in explaining who volunteers”, Voluntary Sector Review, Vol.6 No.1, pp.3-19.

Holmes, K. and Smith, K. (2012), Managing volunteers in tourism, Routledge.

Kemp, S. (2002), “The hidden workforce: Volunteers' learning in the Olympics”, Journal of European Industrial Training, Vol. 26 No. 2, pp.109-116.

Murzyn-Kupisz, M. and Działek, J. (2013), "Cultural heritage in building and enhancing social capital", Journal of Cultural Heritage Management and Sustainable

Development, Vol. 3 No. 1, pp. 35-54.

National Trust Annual Report (2016) available at:

https://www.nationaltrust.org.uk/features/annual-reports (accessed August 27, 2017)

National Trust Dunham Massey (2017) available at:

https://www.nationaltrust.org.uk/dunham-massey (accessed August 27, 2017)

National Trust Dunham Massey Collections (2017) available at:

http://www.nationaltrustcollections.org.uk/place/dunham-massey (accessed August 22, 2017)

National Trust, Dunham's Lost Years (2016) available at:

https:/www.nationaltrust.org.uk/dunham-massey/features/dunhams-lost-years-a-victoriantale-of-love-and-abandonment (accessed 8 September 2017)

National Trust Fascinating Facts and Figures (2017) available at:

https://www.nationaltrust.org.uk/lists/fascinating-facts-and-figures(accessed August 27, 2017)

National Trust, Our plan to nurse the environment back to health (2016) available at: https://www.nationaltrust.org.uk/news/our-plan-to-nurse-environment-back-to-health (accessed September 6, 2017)

Newton, C., Becker, K. and Bell, S. (2014), "Learning and development opportunities as a tool for the retention of volunteers: a motivational perspective", Human Resource Management Journal, Vol. 24 No. 4, pp. 514-530.

NCVO (2016) The Voluntary Sector, Volunteers and workforce, UK Civil Society Almanac. 
OECD (2017), Gender equality in volunteering, available at:

http://www.oecd.org/gender/data/women-are-catching-up-to-men-in-volunteering-and-theyengage-in-more-altruistic-voluntary-activities.htm (accessed August 22, 2017)

Rochester, C., Paine, A.E., Howlett, S. and Zimmeck, M. (2010), Volunteering and Society in the $21^{\text {st }}$ Century, Palgrave Macmillan, Basingstoke.

Rowley, J. (2002), "Using case studies in research”, Management Research News, Vol. 25 No.1, pp. 16-27.

Stamer, D. Lerdall, K. and Guo, C. (2008), "Managing heritage volunteers: an exploratory study of volunteer programmes in art museums worldwide", Journal of Heritage Tourism, Vol.3 No.2, pp. 201-214.

Studer, S. (2015), "Volunteer Management Responding to the Uniqueness of Volunteers", Non-profit and Voluntary Sector Quarterly, Vol. 45 No. 4, pp. 688-714.

Vecina, M. L., Chacon, F., Sueiro, M. and Barron, A. (2012), "Volunteer engagement: does engagement predict the degree of satisfaction among new volunteers and the commitment of those who have been active longer?", Applied Psychology, Vol.6 No.1, pp. 130-148.

Volunteering England and the TUC (2009) A Charter for Strengthening Relation Between Paid Staff and Volunteers, Volunteering England, London

Wilson, J. (2012), "Volunteerism research: A review essay", Non-profit and Voluntary Sector Quarterly, Vol. 41 No. 2, pp. 176-212.

Yin, R.K. (1994), Case Study Research: Design and Methods, Sage, Thousand Oaks, CA. 